\title{
PENINGKATAN KEMAMPUAN PEMAHAMAN KONSEP MATEMATIS MELALUI MODEL PEMBELAJARAN KOOPERATIF TIPE THE POWER OF TWO (TPOT) DAN THINK TALK WRITE (TTW)
}

\author{
Meti Tambunan ${ }^{1}$, Kartini Hutagaol ${ }^{2}$ \\ Fakultas Keguruan dan Ilmu Pendidikan \\ Universitas Advent Indonesia \\ 12angelinemarlina75@gmail.com, ${ }^{2}$ kartinihutagaol21@gmail.com
}

\begin{abstract}
Abstrak: Penelitian ini bertujuan untuk meningkatkan kemampuan pemahaman konsep matematis siswa SMP. Penelitian dengan desain komparatif ini dilakukan dengan menggunakan dua model pembelajaran kooperatif yaitu tipe The Power Of Two (TPOT) dan tipe Think Talk Write (TTW). Sampel dalam penelitian ini dua kelas VII SMPN 3 Lembang, Bandung Barat. Instrumen yang digunakan adalah tes kemampuan pemahaman konsep matematis pada pokok bahasan Aritmatika Sosial yang berupa tes uraian dan angket respon siswa. Temuan dari hasil penelitian ini adalah bahwa peningkatan kemampuan pemahaman konsep matematis pada siswa yang memperoleh pembelajaran yang menggunakan model kooperatif tipe The Power Of Two (TPOT) sebesar 0,85 dan siswa yang memperoleh pembelajaran dengan menggunakan model kooperatif tipe Think Talk Write (TTW) sebesar 0,83 termasuk dalam kategori tinggi. Tidak terdapat perbedaan yang signifikan pada peningkatan kemampuan pemahaman konsep matematis siswa antara siswa yang memperoleh model kooperatif tipe The Power Of Two (TPOT) dan siswa yang memperoleh pembelajaran dengan menggunakan model kooperatif tipe Think Talk Write (TTW). Siswa senang dengan model pembelajaran kooperatif The Power Of Two (TPOT).
\end{abstract}

Kata Kunci: Kemampuan Pemahaman Konsep Matematis, Pembelajaran Kooperatif, The Power Of Two (TPOT), Think Talk Write (TTW)

Abstract: This study aims to improve the mathematical concepts comprehension of junior high school students. This comparatively designed study was carried out by using two cooperative learning models, namely The Power of Two (TPOT) type, and the Think Talk Write (TTW) type. This study was carried out at two classes from class VII of SMPN 3 Lembang, West Bandung. The instrument used was a test of mathematical concepts comprehension on the subject of Social Arithmetic in the form of subjective tests and student response questionnaires. The findings from the results of this study are that an increase in the mathematical concepts comprehension in students who obtained the cooperative model The Power Of Two (TPOT) type is 0.85 , and students who obtained the Think Talk Write (TTW) type cooperative model is 0.83, which are both in the high category. There was no significant difference in the improvement of students' mathematical concepts comprehension between students who obtained the cooperative model The Power Of Two (TPOT) type and students who obtained the Think Talk Write (TTW) type cooperative model. Students are happy with the cooperative learning model The Power Of Two (TPOT) type.

Keyword: Mathematical Concepts Comprehension, Cooperative Learning, The Power Of Two (TPOT), Think Talk Write (TTW). 


\section{PENDAHULUAN}

Matematika adalah salah satu ilmu pengetahuan yang sangat berguna untuk menyelesaikan masalah dalam kehidupan sehari-hari, baik dalam bidang perekonomian, bidang kesehatan ataupun hal lainnya. Matematika sebagai sarana yang berguna untuk melatih daya fikir dan kreaktifitas seseorang.

Dalam Permendiknas Nomor 22 Tahun 2011 tentang standar isi, dan tujuan mata pelajaran matematika, dinyatakan bahwa siswa hendaknya memiliki kemampuan untuk: (1) Memahami konsep matematika: (2) Menggunakan penalaran; (3) Memecahkan masalah; (4) Mengkomunikasikan gagasan; (5) Memiliki sifat menghargai kegunaan matematika. Salah satu dari kemampuan tersebut adalah kemampuan pemahaman konsep. Pemahaman konsep membutuhkan analisis yang mendalam, yang bukan sekadar mengetahui atau mengingat konsep yang dipelajari, tetapi mampu mengungkapkan kembali dalam bentuk lain yang mudah dimengerti, memberikan interprestasi data dan mampu mengaplikasikan konsep yang sesuai dengan struktur kognitif yang dimilikinya (Sanjaya, 2009).

Pemahaman konsep matematis tersebut sangat penting, di mana melalui penguasaan konsep tersebut akan mempermudah siswa dalam mempelajari matematika. Dalam setiap pembelajaran matematika, diusahakan lebih menekankan pada konsep, agar siswa dapat memiliki bekal dasar yang baik untuk mencapai kemampuan dasar. Dalam Hutagaol (2018) dijelaskan bahwa dalam melakukan pengajaran matematika di sekolah guru cenderung mengutamakan kepada hapalan, hasil. Untuk itu, sebaiknya para guru bidang studi matematika sebaiknya menekankan pada pemahaman konsep agar setiap siswa dapat dengan mudah menemukan, dan menjelaskan bahkan menyimpulkan suatu konsep matematika berdasarkan pembentukan pengetahuannya sendiri, bukan hanya sekedar hapalan.

Pemahaman konsep matematis adalah hal utama yang harus dikuasai oleh siswa. Sejalan dengan NCTM (2000) yang menempatkan kemampuan pemahaman konsep matematis siswa menjadi tujuan utama dalam pembelajaran matematika. Susanto (2015) juga menyatakan bahwa untuk mencapai pemahaman yang bermakna, maka pembelajaran matematika harus diarahkan pada pengembangan kemampuan pemahaman konsep matematika antar berbagai ide, memahami bagaimana ide-ide matematika saling terkait satu sama lain sehingga terbangun pemahaman menyeluruh, dan menggunakan matematika dalam konteks diluar matematika. Walle, 2016 juga mengungkapkan bahwa kemampuan pemahaman konsep sangatlah penting pada matematika dan dalam bidang studi lain serta dalam kehidupan sehari-hari sehingga pemahaman konsep matematis sangat diperlukan. 
Kenyataan di lapangan bahwa kemampuan pemahaman konsep matematis masih kurang, hal senada dengan pendapat tim guru SMP Negeri 17 Banjarmasin yang menyatakan bahwa kemampuan pemahaman konsep matematis siswa pada materi bangun ruang masih sangat rendah. Hal ini disebabkan kurangnya pemahaman siswa untuk memahami materi bangun ruang. Siswa kesulitan untuk membedakan antara diagonal bidang dengan bidang diagonal serta kurangnya kemampuan siswa untuk menyelesaikan suatu masalah bangun ruang. Hal tersebut berdampak pada hasil belajar yang dicapai siswa pada materi bangun ruang (Siti, 2016).

Selanjutnya Angga (2012) menyampaikan bahwa menurut penelitian yang dilakukan di kelas VIII di SMP Negeri 3 Batusangkar, didapati bahwa kemampuan pemahaman konsep matematis siswa masih rendah, sekitar 80,5\% kemampuan pemahaman konsep siswa dalam kategori kurang dan sagat kurang sekali. Hal tersebut mengisyaratkan bahwa siswa masih sulit untuk menyelesaikan soal karena kurang paham konsep materi yang diberikan. Fitrah (2016) menyatakan bahwa tidak sedikit peserta didik yang setelah belajar matematika, tidak mampu memahami konsep dari materi yang sudah dipelajari, bahkan pada bagian yang paling sederhana sekalipun, banyak konsep yang dipahami secara keliru sehingga matematika dianggap sebagai ilmu yang sukar, ruwet, dan tidak menarik. Menurut Afrilianto, dkk (2012) faktor yang menyebabkan rendahnya kemampuan pemahaman konsep matematis pada siswa adalah: a. Pendekatan pembelajaran yang digunakan masih kurang untuk membangun pemahaman konsep matematis karena proses pembelajaran hanyalah berpusat pada guru. $b$. Faktor kebiasaan belajar siswa ialah menghafal rumus, sehingga tidak teliti melatih kemampuan pemahaman konsep matematis yang diakibatkan oleh proses pembelajaran konvensional.

Dengan demikian sebagai solusi yang diharapkan untuk dapat meningkatkan kemampuan pemahaman konsep matematis siswa adalah dengan menggunakan model pembelajaran kooperatif tipe The Power Of Two (TPOT) dan pembelajaran tipe Think Talk Write (TTW). Model pembelajaran kooperatif tipe The Power Of Two (TPOT) menurut Suprijono (2009) adalah pembelajaran yang mengajak siswa untuk: (1) mengajukan pertanyaan yang membutuhkan pemikiran kritis; (2) bekerja secara mandiri; (3) mendiskusikan, membandingkan informasi dengan kelompok lain, dan (4) membuat ringkasan dari hasil diskusi dikelas. Hidayat (2009) menyatakan bahwa model pembelajaran kekuatan berdua (The Power Of Two ) adalah kegiatan yang dilakukan untuk meningkatkan belajar kolaboratif dan 
mendorong munculnya keuntungan dari sinergi itu, sebab dua orang itu tentu lebih baik daripada satu orang.

Sedangkan model Think Talk Write (TTW) adalah model pembelajaran yang menekankan pada: (1) belajar dengan berpikir, (2) belajar dengan selalu menuliskan solusi permasalahan soal matematika, (3) mengorganisasikan semua pekerjaan langkah demi langkah, (4) mengoreksi semua pekerjaan sehingga yakin tidak ada pekerjaan ataupun perhitungan yang ketinggalan, (4) meyakini bahwa pekerjaan yang terbaik, lengkap, mudah dibaca dan terjamin keasliannya (Hamdayana, 2014).

Belajar dengan kegiatan yang aktif membuat pembelajaran menjadi menyenangkan dan membuat siswa menjadi tertarik dalam proses pembelajaran dibandingkan hanya dengan mendengarkan guru berceramah (Huda, 2014). Diharapkan dengan menggunakan modelmodel pembelajaran ini dapat mengatasi faktor-faktor penyebab rendahnya kemampuan pemahaman konsep dan mampu meningkatkan kemampuan pemahaman konsep matematis siswa.

Berdasarkan uraian di atas, peneliti merasa terdorong untuk melaksanakan penelitian yang bertujuan untuk menerapkan model pembelajaran kooperatif tipe The Power Of Two (TPOT) dan Think Talk Write (TTW) untuk meningkatkan kemampuan Pemahaman Konsep matematis siswa SMP yang dilakukan dengan membandingkan kelas VII C dan VII B SMPN 1 Parongpong, Bandung Barat.

\section{KAJIAN PUSTAKA}

Pemahaman konsep matematis adalah kompetensi utama yang harus dimiliki siswa. Dengan pemahaman yang mantap maka siswa akan mampu menggunakan dan menerapkan konsep tersebut dalam proses belajar matematika atau dalam permasalahan sehari-hari. Menurut Rohana (2011) bahwa pemahaman konsep yaitu kemampuan seseorang dalam memahami suatu konsep berdasarkan pengetahuan awal yang dimiliki dari apa yang dialaminya, dan menyatukan pengetahuan yang baru ke dalam skema yang ada dengan informasi yang diterima.

Pendapat lain seperti yang diungkapkan oleh Soedjadi (2000) bahwa Pemahaman konsep adalah ide abstrak yang digunakan untuk menggolongkan sekumpulan objek yang biasanya dinyatakan dengan satu istilah atau rangkaian kata. Konsep sangat berperan penting dalam proses pembelajaran, diungkapkan oleh Hamalik (2002) bahwa peranan konsep dalam suatu proses pembelajaran sebagai berikut: 
1. Konsep dapat memperbaiki kerumitan lingkungan.

2. Konsep dapat menolong siswa dalam mengidentifikasi objek-objek yang ada disekitar mereka.

3. Konsep dan prinsip untuk mempelajari sesuatu yang baru, lebih luas dan lebih maju. Siswa tidak harus belajar secara konstan, tetapi dapat membuat konsep-konsep yang telah dimilikinya untuk mempelajari sesuatu yang baru.

4. Konsep dapat menggerakkan kegiatan instrumental.

5. Konsep memperbolehkan untuk pelaksanaan pengajaran.

6. Purwanto (1994) juga menyatakan bahwa pemahaman konsep matematis adalah tingkat kemampuan yang mengharapkan siswa mampu memahami arti atau konsep, situasi serta fakta yang diketahuinya. Dengan demikian secara garis besar pemahaman konsep yaitu Pemahaman konsep yang merupakan dasar utama dalam pembelajaran matematika yang memerlukan pemahaman terhadap konsep-konsep dalam melahirkan teorema atau rumus. Senada dengan hal itu, Putri (2012) menyatakan bahwa kemampuan pemahaman konsep matematis adalah yang berupa penguasaan sejumlah materi pembelajaran, dimana siswa tidak sekedar mengenal dan mengetahui, tetapi mampu mengungkapkan kembali konsep dalam bentuk yang lebih mudah dimengerti serta mampu mengaplikasikannya.

Adapun ndikator-indikator dari kemampuan pemahaman konsep matematis menurut Jihad dan Haris (2010), yaitu: 1.Mengklasifikasikan objek menurut sifat tertentu sesuai dengan konsepnya. 2. Menyajikan konsep dalam bentuk representasi matematis. 3. Meggunakan prosedur atau operasi tertentu. 4. Mengaplikasikan konsep atau alogaritma pemecahan masalah

Model pembelajaran The Power Of Two (TPOT) adalah model pembelajaran yang dilakukan secara berpasangan. Kegiatan pembelajaran ini dapat dilakukan untuk mendorong pembelajaran komparatif dan menegakkan arti penting serta manfaat sinergi dua orang. Strategi in memiliki prinsip bahwa berpikir berdua jauh lebih baik daripada berpikir sendiri (Zaini, dkk, 2008). Dalam model pembelajaran kooperatif tipe The Power Of Two (TPOT) ini siswa dibagi dalam kelompok-kelompok yang beranggotakan empat siswa dengan kemampuan heterogen dan dalam setiap kelompok dibagi dua pasangan.

Dalam kegiatan belajar mengajar harus merumuskan apa yang harus dilakukan siswa dan bagaimana cara mereka melakukan. Ada berbagai macam jenis kegiatan belajar mengajar dalam mempelajari bahan pelajaran antara lain mendengarkan, melihat, mengamati, bertanya, mengerjakan, berdiskusi, memecahkan masalah, mendemonstrasikan, melukiskan atau menggambarkan, mencoba, dan lain-lain (Sardiman, 2014). Dalam implementasi model 
pembelajaran The Power Of Two (TPOT) terdapat prosedur untuk mencapai tujuan pembelajaran secara optimal dan seorang pendidik pun harus dapat menggunakan model belajar The Power Of Two (TPOT) dengan tepat, efektif, dan efisien melalui langkah-langkah model pembelajaran the power of two dalam proses belajar mengajar berlangsung (Putra, 2014).

Think talk write (TTW) merupakan salah satu pembelajaran yang bisa digunakan untuk meningkatkan kemampuan dan keaktifan belajar siswa. Menurut Yamin dan Ansari (2012), model pembelajaran Think Talk Write (TTW) adalah model pembelajaran yang bertujuan untuk berpikir atau berdialog dengan dirinya sendiri, setelah proses membaca masalah (think), selanjutnya berbicara dan membagi ide dengan temannya (talk), dan untuk menyelesaikan masalah tersebut sebelum menulis (write). Think Talk Write (TTW) merupakan model pembelajaran yang memberikan kesempatan untuk berpikir, mendiskusikannya dengan teman kemudian menuliskan hasil dari suatu permasalahan yang diberikan (Yazid, 2012).

Menurut Maula (2012) dalam model pembelajaran Think Talk Write (TPOT) melibatkan tiga tahap penting yang harus dikembangkan dalam pembelajaran matematika, yaitu:

1. Think (berpikir). Dalam pembelajaran siswa membaca teks berupa soal LKS. Pada tahap ini siswa secara individu memikirkan kemungkinan jawaban (strategi penyelesaian), pada tahap ini diperkirakan akan mampu melatih kemampuan pemahaman siswa terhadap konsep yang telah dipelajari Ansari (2003).

2. Talk (berbicara atau diskusi). Memberikan kesempatan kepada siswa untuk membicarakan tentang penyelidikannya pada tahap pertama. Kemampuan komunikasi siswa akan terlihat pada dialognya dalam berdiskusi baik dalam bertukar ide dengan orang lain ataupun refleksi mereka sendiri yang diungkapkannya kepada orang lain Dewi (2010).

3. Write (Menulis). Siswa menuliskan ide-ide yang diperolehnya dari kegiatan tahap pertama dan kedua. Pada tahap ini diperkirakan akan lebih melatih kemampuan pemahaman konsep matematika siswa dalam memahami kalimat matematika Andriani (2008).

\section{METODE PENELITIAN}

Metode pengumpulan data adalah cara bagaimana peneliti mengumpulkan data penelitiannya data penelitiannya. Penelitian yang bersifat komparatif (membandingkan) antara dua kelas dengan pembelajaran berbeda yaitu pembelajaran kooperatif tipe The Power Of Two (TPOT) dan Think Talk Write (TTW). Populasi dari penelitian ini adalah siswa SMP kelas VII 
di Kabupaten Bandung Barat. Sampel dari penelitian ini adalah dua kelas siswa kelas VII SMP Negeri 1.

Istumen penelitian yang digunakan dalam penelitian ini adalah tes dan non tes. Instrumen tes berupa kemampuan kemampuan pemahaman konsep, sedangkan untuk instrumen non-tes berupa angket. Instrumen penelitian ini dilakukan sebagai bentuk usaha agar mendapatkan data dan informasi yang lengkap untuk memenuhi kajian dalam penelitian.

Data yang akan diperoleh dari penelitian ini adalah hasil dari pretes dan postes serta dari angket respon siswa maka akan dilakukan pengolahan data secara keseluruhan menggunakan SPSS untuk melihat peningkatan kemampuan pemahaman konsep matematis siswa yang mendapatkan pembelajaran dari The Power Power Of Two (TPOT) dan hink Talk Write (TTW) yaitu:

(1) Analisis dilakukan dengan menggunakan gain ternomarlisasi yang diperkenalkan oleh Hake :

$$
(\mathrm{g})=\frac{\text { postes }- \text { pretes }}{100-\text { pretes }}
$$

(2) Digunakan uji normalitas dengan uji Shapiro-Wilk (Razali dan wah 2011) dengan taraf signifikansi $5 \%$.

$$
\mathrm{W}=\frac{\left(\sum_{i=1}^{n} a_{i} x_{(i)}\right)^{2}}{\left(\sum_{i=1}^{n}\left(x_{1}-\bar{x}\right)\right)^{2}}
$$

Uji normolitas dilakukan untuk mengetahui data yang digunakan merupakan data yang berdistribusi normal atau tidak. Hipotesis untuk tes ini adalah $H_{0}$ : populasi data berdistribusi normal. Jika data diolah dengan menggunakan SPSS, kriteria penolakan $H_{0}$ adalah sebagai berikut

$H_{0}$ ditolak jika sig. $\leq 0,05$

$H_{0}$ tidak ditolak jika nilai sig. $>0,05$

(3) Menghitung nilai F (tingkat homogenitas)

$$
F_{\text {hitung }}=\frac{S^{2} \text { terbesar }}{S^{2} \text { terkecil }}
$$

Uji homogenitas digunakan untuk mengetahui apakah kedua kelompok itu memiliki varians homogen atau tidak. Hipotesis untuk tes ini adalah $H_{0}$ : populasi data berdistribusi homogen. 
Jika $F_{\text {hitung }} \leq F_{\text {tabel }}$ maka varian populasi data tersebut homogen.

Kriteria berdasarkan penolakan data, pada penelitian ini yaitu

$H_{0}$ ditolak jika nilai sign. $\leq 0,05$

$H_{0}$ tidak ditolak jika nilai sign. $>0,05$

(4) Uji beda dua rata-rata bertujuan untuk membandingkan atau mengetahui perbedaan peningkatan kemampuan koneksi matematis siswa pada dua kelompok komparatif tersebut.

$$
\begin{gathered}
S_{\text {gab }}=\sqrt{\frac{\left(\mathrm{n}_{1}-1\right) \mathrm{s}_{1}^{2}+\left(\mathrm{n}_{2}-1\right) \mathrm{s}_{2}{ }^{2}}{\mathrm{n}_{1}+\mathrm{n}_{2}-2}} \\
\mathrm{t}_{\text {hitung }}=\frac{\overline{\mathrm{x}_{1}}-\overline{\mathrm{x}_{2}}}{\mathrm{~s}_{\mathrm{gab}} \sqrt{\frac{1}{\mathrm{n}_{1}}+\frac{1}{\mathrm{n}_{2}}}}
\end{gathered}
$$

Pengujian dilakukan menggunakan software SPSS dengan kriteria penolakan $\mathrm{H}_{0}$ adalah: tolak $\mathrm{H}_{0}$ jika $\geq t_{\alpha}$, dengan $\alpha=0,05$.

Analisis respon siswa dengan presentasi respon positif $(\mathrm{P})$ :

$$
P=\frac{h}{n} \times 100 \% \quad \text { (Arikunto, 2012) }
$$

\section{HASIL PENELITIAN}

Data dari hasil penelitian ini adalah hasil pretes, postes dan gain ternormalisasi pada kedua kelompok. Data diolah dengan menggunakan bantuan software SPSS versi 21.0 for windows.

1. Rata-rata skor pretes kemampuan pemahaman konsep matematis siswa yang memperoleh model pembelajran kooperatif tipe The Power Of Two (TPOT) sebesar 9,69. Sedangkan rata-rata skor pretes kemampuan pemahaman konsep siswa yang memperoleh model pembelajran kooperatif tipe Think Talk Write (TTW) sebesar 9,11. Rata-rata skor pretes kemampuan pemahaman konsep matematis siswa pada kedua kelompok tersebut sedang. Pernyataan tersebut dapat dilihat dari skor maksimal ideal (SMI=28). Dilihat dari standard deviasi, kelompok The Power Of Two (TPOT adalah lebih kecil dari standard deviasi kelompok Think Talk Write (TTW). Artinya, sebaran data skor pretes kelompok Think Talk Write (TTW) mendekati rata-rata dibandingkan dengan sebaran skor pretes kelompok The Power Of Two (TTW) 
2. Rata-rata skor postes kemampuan pemahaman konsep matematis kelompok model pembelajran kooperatif tipe The Power Of Two (TPOT) sebesar 25,17. Sedangkan kelompok model pembelajran kooperatif tipe Think Talk Write (TTW) sebesar 25,06. Rata-rata postes mengalami peningkatan dari rata-rata pretes. Dilihat dari strandard deviasi, kelompok model pembelajaran kooperatif tipe Think Talk Write (TTW) lebih besar dari standar deviasi kelompok model pembelajaran kooperatif tipe The Power Of Two (TPOT). Artinya, sebaran data skor postes kelompok The Power Of Two (TPOT) mendekati rata-rata dibandingkan dengan skor postes kelompok Think Talk Write (TTW).

3. Rata-rata gain ternormalisasi kemampuan pemahaman konsep matematis siswa kelompok model pembelajaran kooperatif tipe The Power Of Two (TPOT) sebesar 0,85 Sedangkan skor gain ternormalisasi kelompok model pembelajran kooperatif tipe Think Talk Write (TTW) sebesar 0,83. Hal ini menunjukkan bahwa peningkatan kemampuan pemahaman konsep matematis siswa pada kedua kelompok masuk dalam kategori tinggi dilihat dari indeks gain $\mathrm{G} \geq 0,70$. Dilihat dari standard deviasi, kelompok Think Talk Write (TTW) lebih tinggi dari kelompok The Power Of Two (TPOT). Sebaran rata-rata skor gain ternormalisasi kelompok Think Talk Write (TTW) lebih mendekati rata-rata dibandingkan kelompok The Power Of Two (TPOT).

Tabel 1 Uji Normalitas Gain Ternomalisasi

\begin{tabular}{|l|l|l|l|l|}
\hline \multirow{2}{*}{ Kelompok } & Shopiro-Wilk & \multicolumn{3}{|c|}{ Keterangan } \\
\cline { 2 - 5 } & Statistic & Df & Sig. & \\
\hline TPOT & 0,94 & 35 & 0,102 & H0 tidak ditolak \\
\hline \multirow{2}{*}{ TTW } & 0,91 & 35 & 0,12 & H0 tidak ditolak \\
\hline
\end{tabular}

Nilai signifikan gain ternomalisasi dari kedua kelompok tersebut kedua menunjukan lebih besar dari 0,05 berdistribusi normal yaitu kelompok kelas yang mendapatkan model pembelajaran kooperatif tipe The Power Of Two (TPOT) dan tipe Think Talk Write (TTW). Hal ini berarti, Uji normalitas gain ternornalisasi dari kedua kelompok tersebut berdistribusi normal. Karena itu, untuk mengguji beda dua rata-rata dengan mengunakan uji statistik t-test.

Tabel 2 Uji Homogenitas Gain Ternormalisasi

\begin{tabular}{|l|l|l|l|}
\hline Levene Statistic & Df 1 & Df 2 & Sig. \\
\hline 0,000 & 1 & 68 & 0,990 \\
\hline
\end{tabular}


Terlihat bahwa nilai signifikan gain ternormalisasi lebih besar dari 0.05 oleh sebab itu $H_{0}$ tidak tolak, sehingga data gain ternormalisasi dari kedua kelompok kelas tersebut adalah homogen.

Tabel 3 Uji Beda Dua Rata-rata Gain Ternomalisasi

\begin{tabular}{|c|c|c|c|c|c|c|}
\hline \multirow{3}{*}{$\begin{array}{l}\text { Gain: } \\
\text { Equal } \\
\text { Variance } \\
\text { Assumed }\end{array}$} & \multicolumn{2}{|c|}{$\begin{array}{l}\text { Leven's Test For Equality } \\
\text { Of Variance Assumed }\end{array}$} & \multicolumn{4}{|c|}{ t-test for equality means } \\
\hline & $\mathrm{F}$ & Sig. & $\mathrm{t}$ & Df1 & Df2 & $\begin{array}{r}\text { Sig } \\
(2-\text { tailed) }\end{array}$ \\
\hline & 0.000 & 0,990 & 0,292 & 1 & 68 & 0,772 \\
\hline
\end{tabular}

Signifikasi (2-tailed) lebih besar dari 0.05 maka $H_{0}$ tidak ditolak. Hal ini berarti, tidak ada perbedaan yang signifkan pada peningkatan kemampuan pemaahman konsep matematis siswa yang memperoleh kedua model pembelajaran kooperatif yaitu The Power Of Two (TPOT) dan Think Talk Write (TTW). Kelompok kelas yang mendapatkan model pembelajaran kooperatif The Power of Two (TPOT) memiliki presentase sebesar 83,93\% dalam kategori "sangat suka". Sedangkan, kelompok kelas yang mendapatkan model pembelajaran kooperatif Think Talk Write (TTW) memiliki presentase sebesar 69,71 \% dalam kategori "biasa saja.”

\section{KESIMPULAN}

Kesimpulan yang didapatkan dari hasil pengolahan data penelitian dan pembahasan antara lain :

1. Peningkatan kemampuan pemahaman konsep matematis siswa melalui model pembelajaran kooperatif tipe The Power Of Two (TPOT) dan Think Talk Write (TTW) berada pada kategori sedang.

2. Tidak ada perbedaan yang signifikan terhadap peningkatan kemampuan pemahaman konsep matematis siswa melalui model pembelajaran kooperatif tipe The Power Of Two (TPOT) dan Think Talk Write (TTW).

3. Respon siswa terhadap pembelajaran matematika dengan mengunakan model pembelajaran kooperatif tipe The Power Of Two (TPOT) berada pada kategori sangat senang yang berarti model pembelajaran kooperatif tipe The Power Of Two (TPOT) sangat disenangi dalam penerapannya pada pelajaran matematika dan Think Talk Write (TTW) berada pada kategori biasa yang artinya model pembelajaran kooperatif tipe Think Talk Write (TTW) mendapat respon biasa saja dalam penerapannya pada pelajaran matematika. 


\section{SARAN}

Berdasarkan hasil penelitiaan dan kesimpulan. Maka, penulis merekomendasikan beberapa saran yang berhubungan dengan penelitian yang dilakukan berikut :

1. Guru dapat membandingkan model pembelajaran kooperatif The Power Of Two (TPOT) dan Think Talk Write (TTW) sebagai salah satu alternatif untuk membuat pembelajaran matematika yang lebih efektif dan tidak membosankan.

2. Dalam pembelajaran matematika hendaknya guru dapat mengatur suasana belajar yang efisien dan memberikan contoh-contoh yang konkret dalam kehidupan sehari-hari, sederhana dan mudah dimengerti siswa dalam pemahaman materi pelajaran.

3. Hasil penelitian ini hendaknya dapat menjadi referensi bagi peneliti yang lain untuk penelitian yang lebih lanjut dengan aspek kemampuan/variabel penelitian yang berbeda.

\section{DAFTAR PUSTAKA}

Afrilianto, M. (2012). Peningkatan Pemahaman Konsep dan Kompetensi Strategis Matematis Siswa SMP dengan Pendekatan Metaphorical Thinking. Jurnal Ilmiah Program Studi Matematika STKIP Siliwangi Bandung, Vol. 1, No. 2 Hal. 192-202.

Andriani, M. (2008). Mengembangkan Kemampuan Komunikasi Dan Pemecahan Masalah Matematika Siswa Madrasah Ibtidaiyah Melalui Strategi Think-Talk-Write Berbasis Modul, Thesis, (Online), (http://mellyirzal.blogspot.com/2008/12/strategipembelajran-think-talkwrite.html), diakses tanggal 20 Januari 2013

Ansari, (2003) Menumbuhkembangkan Kemampuan Pemahaman dan Komunikasi Matematika Siswa SMU melalui Strategi Think Talk Write, Disertasi, (Online), (http://digilib.upi.edu/digitalview.php?digital_id=1161)

Dewi, (2010). Implementasi Pembelajaran Kooperatif tipe TTW (Think Talk Write) dalam upaya Meningkatkan Kemampuan komunikasi matematika pada siswa kelas VII SMP negeri 1 Talun. Skripsi tidak diterbitkan. Malang.UM

Hamalik, O. (2004). Proses Belajar Mengajar. Jakarta: Bumi Aksara.

Hamdayana, J. (2014). Model dan Metode Pembelajaran Kreatif dan Berkarakter. Bogor: Ghalia Indonesi.

Hidayat, (2009). Active Learning. Yogyakarta: Pustaka Insan Madani.

Hutagaol, K. (2018). Strategi Multi Representasi dengan Kemampuan Pemecahan Masalah Matematis Siswa. Jurnal Padegogik Vol.01 no.1 Hal. 1-11.

Jihad, A. H. (2010). Evaluasi Pembelajaran. Yogyakarta: Multi Pressindo.

Maula, N. (2012). "Model pembelajaran Think-Talk-Write (TTW)" (Online), (http://maulanikmatul.blogspot.com/2012/01/model-pembelajaran-think-talk-writettw.html), diakses tanggal 17 Maret 2013.

NCTM. (2000). Principles and standards for school mathematics. Reston, VA: NCTM.

Purwanto, M. N. (1994). Prinsip-prinsip dan Teknik Evaluasi Pengajaran Pendidikan: Bandung.

Putra, E, A. 2014. Pengaruh Strategi Pembelajaran The Power of Two Berbantuan Media Belajar

Putri, (2012). Pemahaman Konsep Matematika Pada Materi Turunan Melalui Pembelajaran Teknik Probing. Jurnal Pendidikan Matematika, Vol. 1 No 1, Part 2: Hal. 68-72. 
Rohana, (2011). Pengaruh Pembelajaran Berbasis Masalah Terhadap Pemahaman Konsep Mahasiswa FKIP Universitas PGRI. Palembang: Prosiding PGRI

Sardiman, (2014). Interaksi dan Motivasi Belajar Mengajar. Jakarta: PT. Raja Grafindo Persada

Soedjadi, R. (2000). Kiat Pendidikan Matematika di Indonesia. Jakarta: Direktorat Jendral Pendidikan Nasional.

Susanto, A. (2015). Teori Belajar dan Pembelajaran di Sekolah Dasar. Prenadamedia Group, Jakarta

Sanjaya, W. (2009). Strategi Pembelajaran Berorientasi Standar Proses Pendidikan. Jakarta: Kencana Prenada Media Group.

Walle, J. A. (2016). Matematika Sekolah Dasar dan Menengah. Jakarta: Erlangga.

Yamin, Martinis \& Bansu I. A. (2012). Taktik Mengembangkan Kemampuan Individual Siswa. Jakarta:

Yazid, A. (2012). Pengembangan Perangkat Pembelajaran Matematika Model Kooperatif dengan Strategi TTW (Think-Talk-Write) pada Materi Volume Bangun Ruang Sisi Datar. Jurnal Of Primary Educational. Vol 1(1). Hal 31-37)

Zaini, H. dkk. (2008). Strategi Pembelajaran aktif. Yogyakarta: Pustaka Insan Madani.

Siti, (2016). Kemampuan Pemahaman Konsep Matematis Siswa SMP dalam Pembelajaran Menggunakan Model Penemuan Terbimbing (Discovery Learning). EDU-MAT Jurnal Pendidikan Matematika, Vol. 4, No. 1, Hal. 76-85. 